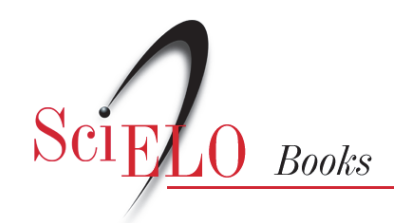

\title{
Vendido a um-que-não-existe: \\ privação, presença e confissão no Grande Sertão
}

\author{
Andrei Soares
}

FERRAZ, S., et al.,orgs. Deuses em poéticas: estudos de literatura e teologia [online]. Belém: UEPA; Campina Grande: EDUEPB, 2008. 364 p. ISBN 978-85-7879-010-3. Available from SciELO Books $<\underline{\text { http://books.scielo.org }>\text {. }}$

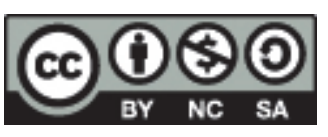

All the contents of this work, except where otherwise noted, is licensed under a Creative Commons Attribution-Non Commercial-ShareAlike 3.0 Unported.

Todo o conteúdo deste trabalho, exceto quando houver ressalva, é publicado sob a licença Creative Commons Atribuição Uso Não Comercial - Partilha nos Mesmos Termos 3.0 Não adaptada.

Todo el contenido de esta obra, excepto donde se indique lo contrario, está bajo licencia de la licencia Creative Commons Reconocimento-NoComercial-CompartirIgual 3.0 Unported. 


\section{Vendido a um-que-não-exis- te: privação, presença e con- fissão no Grande Sertão \\ Andrei Soares}




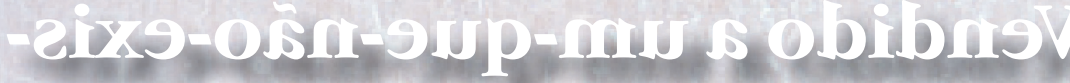

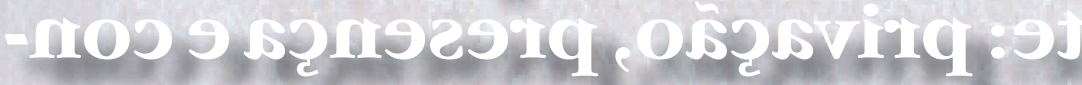

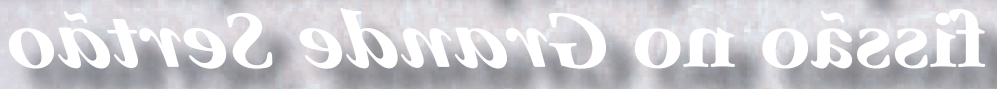

297002 j9nborA 
Resumo: O trabalho explora o encontro entre artifício e ausência, um encontro definido pela impossibilidade de se representar, articular ou mesmo conceber aquilo (ou aquele) que inexiste. Mais especificamente, discute como João Guimarães Rosa logra em Grande Sertão: Veredas (GSV) sugerir a presença, no próprio cerne da experiência narrada, de uma privação radical e diabólica - privação que, entretanto, jamais chega a representar na narrativa. Recorrendo a Agostinho, Pseudo-Dionísio e Boécio, o trabalho sugere que essa ausência do diabo apropria, rearticula e por fim subverte - por hipérbole - um procedimento neoplatônico constitutivo da teologia Cristã: a tipificação do mal como mero privatio boni ou falta do bem.

Palavras-chave: teodicéia, teologia negativa, ontologia, privatio boni, Grande Sertão: Veredas.

Summary: The article explores the encounter of artifice and absence, an encounter defined by the impossibility of adequately representing, articulating or even conceiving that which does not exist. More specifically, it discusses how João Guimarães Rosa avoids in Grande Sertão: Veredas depicting radical diabolic privation even while suggesting its unqualified - even deictic - presence in the immediacy of represented experience. Resorting to Augustine, Pseudo-Dionysius and Boethius, it suggests that this absence of the devil appropriates, rearticulates, hyperbolizes and subverts a neo-platonic procedure constitutive of Christian theology: the tipification of evil as mere privatio boni, or absence of good.

Keywords: theodicy, negative theology, ontology, privation boni, Grande Sertão: Veredas.

\footnotetext{
* É jornalista, mestre em Literatura Comparada pela City University of New York (CUNYGC), doutorando em Literatura Comparada pela University of Pennsylvania (PENN) e leitor por prazer. Seus principais interesses acadêmicos são pensamento social latinoamericano, interseções entre literatura e teologia e crítica ideológica. E-mail: andreisds@ hotmail.com
} 
A modernidade é um cosmo imanente.

Jakob Taubes

Não como o mundo é, mas que ele é, é o místico.

Ludwig Wittgenstein

\section{Ser e não ser no sertão}

Abertura de Grande Sertão: Veredas. Ainda no início da confissão ficcional que constitui a obra-prima de João Guimarães Rosa, o narrador Riobaldo recorre a um contraste inusitado para distinguir o divino do diabólico. "O senhor não vê?", começa o ex-jagunço, evocando - para o espaço pragmático da narrativa, para seu aqui fictício - aquele misterioso interlocutor cuja visita motiva a sua fala. E acrescenta, em uma das passagens mais enigmáticas do romance:

O que não é Deus, é estado do demônio. Deus existe mesmo quando não há. Mas o demônio não precisa de existir para haver - a gente sabendo que ele não existe, aí é que ele toma conta de tudo. $\mathrm{O}$ inferno é um sem-fim que nem não se pode ver. Mas a gente quer Céu é porque quer um fim: mas um fim com depois dele a gente tudo vendo. (ROSA, 1984, p. 56 , negrito nosso).

Está claro que existe entre Deus e o diabo oposição marcada por um delicado jogo de ser e não ser - um jogo que remete também a questões de presença, privação e atualidade. Mas trata-se de uma oposição paradoxal. Pois os termos da antítese se desfazem em duas contradições: a de um que existe sem haver e a de outro que há quando inexiste. Para distinguir entre as forças antagônicas do divino e do diabólico, Riobaldo usa o par sinonímico "existir" e "haver". Referencialmente, os verbos são análogos, quase idênticos. Denotam atualidade, qualidade do que é. Mas o diabo está nos detalhes - e, nesse caso, na sutil diferença entre o que cada verbo conota: o existir, uma solidez ontológica intransitiva e pessoal; e o haver, o espectro de uma presença impessoal.

"Deus existe mesmo quando não há." Intransitiva, sua ex-sistentia determina a si mesma. Etimologicamente, "apresenta-se", "manifesta-se" e "coloca-se à vista". É, gramatical e teologicamente, sujeito do próprio ato de ser. Pois a externalização implícita no prefixo ex- estabe- 
lece que seu ser antecede qualquer manifestação e independe de testemunho. Não precisa do aval ou do reconhecimento de outrem para ser. Autogerado, existe a si próprio.

"Deus existe mesmo quando não há." Ainda ausente ou despercebido, possui a atualidade irrestrita de quem - já no Êxodo - apresenta-se com a expressão "EU SOU O QUE SOU". Não há redundância ou tautologia nessa denominação, pois ela não se propõe a fixar uma referência ou exaustar o Deus que se descreve com ela. Expressiva, sugere a hiperessência e o poder criador verbal de um que é o que é não pela tautologia de ser o que é, mas - isso sim - pela plenitude de ser a própria origem de todo ser, plenitude que supera tanto a ontologia que possibilita quanto as possibilidades da expressão humana.

O demônio não é menos enigmático. Presença impessoal e fenomenal, "não precisa de existir para haver", pois surge no centro desse defectivo "haver". Trata-se de um verbo único por desvencilhar o ser daquele que é, sugerindo um que não é sujeito do seu ser, mas pode ainda assim estar nessa página, nessa rua, no meio desse redemoinho. Descrito no Novo Testamento como bo arkon tou kosmou, é "o príncipe desse mundo3". Seu "estado"” - termo a compreender no duplo sentido de um "domínio político" espacial e de uma "condição momentânea" temporal - é o local vivido, a dêixis de cada aqui.

É, de fato, nesse aqui que o demônio se manifesta sem ser. Ainda que seja o príncipe desse mundo, seu reinado sofre de uma transitividade tanto gramatical quanto ontológica: não é sujeito de um ser próprio, mas objeto de um ser alheio. "Misturado em tudo", o diabo é o que "opõe" ou "lança no caminho" do que é (ROSA, 1984. p. 11). E dessa etimologia surge um espanto de linguagem: a complementaridade entre o dia-bolos grego que lança e o ob-jectum latino que é lançado. O que é pra ser, parece, são mesmo as palavras.

"O demônio não precisa de existir para haver". Quanto mais inexiste, quanto mais se afasta do que é e Daquele (ou Daquela) que é-o-que-é, mais diabólico se faz e mais "toma conta de tudo". Há, por-

2 Êxodo 3: 14. Jack Miles enfatiza a natureza polissêmica da autodenominação usada por Deus, cuja forma Hebraica original, Ehyeh-Asher-Enyeh, permite leituras que variam do habitual "EU SOU O QUE SOU" ao profético "eu sou o que serei", passando pelo aristotélico "eu sou o que faço". (1995. pp. 120-121). Aos possíveis significados do nome divino, vale também lembrar o causal "eu faço ser aquilo que eu faço ser", cuja ênfase na capacidade geradora e causal da divindade é enfatizada por Gowan (1994. pp. 82-83).

3 No quarto evangelho, atribuído a João, Jesus menciona o príncipe desse mundo em três ocasiões - prevendo sua derrota, julgamento e expulsão (12:31, 14:30 e 16:11) 
tanto, nesse "haver" a presença paradoxal de um que não existe, um "Que-Não-Há", mas age ainda assim ${ }^{4}$. E é nessa ausência, nessa falta constitutiva, que reside sua capacidade de "divertir a gente com sua dele nenhuma existência." (ROSA, 1984. p. 292). "O diabo não existe", enfatiza Donaldo Schuler: "Mas precisamente por não ser é que ele é perigoso. Ameaça reduzir ao que não é aquilo que é." (1969. p. 70).

Schuler não foi o único a reconhecer a importância dessa ausência no projeto mito-poético que é Grande Sertão. Em seu clássico As formas do falso, Walnice Nogueira Galvão ressalta a associação, pelo narrador roseano, de Deus com um "princípio positivo" do cosmos associação que admite "a existência de um princípio negativo que leva o nome de Diabo" (1972. p. 129). Também João Adolfo Hansen enfatiza a privação ontológica do diabo, sua paradoxal condição de ter "real existência de não-ser, lembrando o Outro platônico." (2000. p. 89-90).

Ainda não é momento de dar a Galvão e Hansen a atenção que merecem. Por enquanto, basta fazer um elogio e uma ressalva aos dois rosistas. O elogio é reconhecer que suas vigorosas leituras são ambas perspicazes ao enfatizar a tanto a negatividade radical do diabo quanto a sua importância como símbolo da incerteza e da indeterminação. Já a ressalva é enfatizar que nenhuma das duas problematiza a fascinante relação que existe entre o "Que-Não-Há" roseano e o diabo da tradição cristã.

As leituras de Galvão e Hansen não perdem importância por isso, pois ambas desvendam questões igualmente legítimas, pertinentes e o que é mais importante - interessantes. Mas nem por isso deixam de exemplificar uma relutância da critica em explorar os vários pontos de encontro entre a teologia e Guimarães Rosa - cuja obra ora se distancia da teologia cristã, ora se inscreve nela e ora a subverte por dentro5. É o que ocorre no caso da diabologia ocidental - no cerne da qual o escritor brasileiro encontra o paradoxo constitutivo desse diabo que, mesmo sem ser, há.

\footnotetext{
4 ROSA, 1984. p. 55. Outras variantes do nome descritivo são "um-que-não-existe" (130) e "o-que-não-existe" (282). Vale ressaltar como, em todos os casos, o uso do hífen atribui um caráter mais atributivo que predicativo a tal inexistência, incorporando-a ao que inexiste. Trata-se, portanto, de um caractônimo semelhante aos formados por particípios substantivais em idiomas declinados.

5 Uma valiosa exceção ao aparente desinteresse do rosismo pela tradição cristã é Heloisa Vilhena de Araújo, cujo Roteiro de Deus tece uma teia de interessantes paralelos entre Grande Sertão, a Commedia de Dante e a escolástica de Tomás de Aquino.
} 


\section{O diabo cristão}

De fato, a antítese tecida por Riobaldo não é nova. Ao contrário, expressa um postulado recorrente na teologia cristã. Trata-se da apresentação do mal enquanto privação sem substância, como a ausência que Agostinho de Hipona - recorrendo ao platonismo radical para refutar a crença maniqueísta em um princípio autônomo da negatividade - tipifica com a pergunta: "O que, afinal, é tudo aquilo que chamamos de mal a não ser a privação do bem?". Em uma teodicéia baseada no contraste entre a abundância de Deus e a vacuidade de outro, o mal é na obra do patrício a mera contaminação, pelo que não é, daquilo que não apenas é, mas também "era bom" desde o início - como o autor sacerdotal do primeiro capítulo de Gênese enfatiza em sete versículos diferentes: 4, 10, 12, 18, 21, 25 e 31.

Codificada por Agostinho, tal tipificação do mal como uma privatio boni, uma privação do bem, tem uma origem ainda mais remota. Pode ser encontrada, ainda que de forma embrionária, nos primórdios da escatologia cristã. No Apocalipse, por exemplo, a instância autoral "João" profetiza o retorno de uma besta que en kai ouk esti kai parestai, "que era e não é e estará presente" . Em um claro contraste, o mesmo "João" exalta a supremacia de um Deus que descreve como bo on kai bo en kai bo erkomenos, como "o que é e que era e que virá (1:4)" - atribuindo assim à diferença entre ser e não ser a própria distinção entre o divino e seu outro.

Agostinho e "João" não são os únicos. Pois tal justaposição entre um Deus que é a fonte de todo ser e um diabo que encarna a privação é um procedimento recorrente na ontologia da Igreja. Encontra-se no

6 Enquirídio 3:11, pp. 5. Agostinho reitera esse ponto nas Confissões (7:12) e em Da moral dos maniqueístas, onde ressalta a falta de substância de todo mal. "O mal não é natureza alguma, se é contrário à natureza”, concede aos maniqueistas $(2: 2,70)$, usando tal negatividade para contestar o dualismo dos mesmos: "Mas o mal é a discordância, que certamente não é uma substância, mas hostil à substância. Para onde leva então? [...] Ele leva tudo que destrói à não existência. Agora, é Deus o autor da existência, e não há existência que, na medida em que existe, leve à inexistência. Assim aprendemos como a discordância não é; quanto a como ele é, nada pode ser dito.” (8:11, p. 72). Tradução da versão inglesa minha.

7 17:8. Pouco antes, João" também tipifica o therion, a besta, como um en kai ouk esti kai mellei anabainein ek tes abussou kai eis apoleian upagei, que "era e não é e está prestes a emergir do abismo e seguir rumo à destruição". Outra variante encontra-se em 17:11. 
Comentário sobre João de Orígenes, para quem "contra o bem está o mal ou a iniqüidade e contra Aquele que é está aquilo que não é, de onde segue que o mal e a iniqüidade são aquilo que não és". Encontrase na Consolação da Filosofia de Boécio, que tece uma teodicéia radical, ao afirmar que o mal reside além do poder de Deus e - portanto - nibil est, cum id facere ille possit qui nibil non potest, "nada é, pois pode aquilo que apenas o nada pode [estar além do poder de Deus]" (Prosa 3, XII, 29). Encontra-se na Moralia de Gregório o Grande, que lendo Jó - enfatiza a marcha rumo ao aniquilamento de Satã: a summa essentia recessit, et per hoc, cotidie excrescente defectu, quasi ad non esse tendit, "como ele caiu da alta essência, e como seu defeito cresce a cada dia, ele se aproxima do não-ser (14: 18)". E recorre na escolástica aristotelizada de Tomás de Aquino, para quem remotio boni privative accepta, mal dicitur, "a remoção do bem, em acepção privativa, chama-se mal"".

Mas talvez a expressão mais enfática dessa não-substancialidade do mal seja Os nomes divinos de Pseudo-Dionísio Areopagita. Pois o místico nega não apenas a existência do mal, mas sua própria inteligibilidade - retratando-o como um oxímoro, como uma contradição avessa a qualquer definição. Torna-o assim uma privação não apenas do bem, mas também de sentido e do "fim com depois dele a gente tudo vendo" que Riobaldo tanto reivindica e tanto busca em seu narrar. Em uma das intermináveis listas que tanto marcam seu estilo, Pseudo-Dionísio é eloqüentemente excessivo ao enfatizar a negatividade abrangente e multifacetada de to kakon:

O mal é contrário aos caminhos, contrário ao desígnio, contrário à natureza, contrário à causa, contrário à origem, contrário à finalidade, contrário à definição, contrário à vontade, contrário à substância. É assim o mal privação, insuficiência, sem força, sem proporção, sem logro, sem beleza, sem vida, sem intelecto, sem motivo, sem completude, sem fundação, sem causa, sem definição,

8 Livro 2, capítulo 7. Tradução da versão inglesa minha. Com a exceção da Summa Teológica, todas a traduções do Latim, idioma que não domino, são feitas por mim a partir de diversas traduções em inglês dos textos em questão. No caso do Grego, idioma que domino pouco, minhas traduções são informadas pelo original e por traduções em inglês. Sempre que possível, cito o original em atenção aos que possam lê-lo.

9 Summa Teológica, 48, art. 3. Como Thomas de Aquino enfatiza repetidamente na questão 48, a "falta" que constitui o mal deve ser compreendida enquanto privação, e não ausência, uma vez que essa levaria tudo o que não existe a ser mal. 
sem resultado; e inativo, debalde, desordenado, dessemelhante, indefinido, obscuro e sem essência, não sendo ele em si nada de nenhuma forma sequer $[\ldots]$ Pois o que em nenhuma forma participa do bem não é nada nem é capaz de qualquer coisa. (4: 32).

Trata-se de um argumento - e uma retórica - tão brilhante quanto eficaz. Ao tipificar o mal como uma privação radical, Pseudo-Dionísio evita abordar o problema sob um registro ético ou vivencial, o que forçosamente o vincularia ao divino. $\mathrm{E}$ o reinscreve sob um registro ontológico que nega sua substancialidade sem, entretanto, negar sua atualidade - preservando assim o divino de qualquer responsabilidade por "sua dele nenhuma existência." (ROSA, 1984. p. 292). Ou seja, o místico reduz o mal àquilo que Riobaldo descreve como "o louco, o doido completo - assim irremediável (219)".

Antes de retornar a Rosa, vale esclarecer um ponto e explicitar outro. O ponto a esclarecer é que o contraste entre a vacuidade do mal e uma divindade que gera (e transcende) todo Ser implica uma teodicéia - um discurso que, citando a feliz expressão de John Milton, busca "reiterar a providência divina e justificar os caminhos de Deus para os homens ${ }^{10}$ ". Como Jeffrey Burton Russell (1988, p. 19) bem ressalta, todo monoteísmo precisa, quando confrontado com o problema do mal, situar-se entre dois opostos: atribuir a Deus a responsabilidade por ele ou admitir a existência de um adversário. Pode, em outras palavras, recorrer a uma teodicéia ou ao dualismo. Cada estratégia tem seu preço. Enquanto o dualismo compromete a onipotência do divino, a teodicéia corre o risco de negar a experiência e a subjetividade ao tecer uma solução apenas metafísica para um problema imediato: o sofrimento real.

A despeito de seus esforços, a retórica do privatio boni não logra a superação do mal ou do dualismo. Logra apenas a transposição dos dois problemas de um registro vivencial para um ontológico - e, portanto, metafísico. Não elimina a experiência real do mal - seja ele natural, humano ou radical. Como todo muthos - toda história ou narrativa -, apenas adia a contradição que diz explicar, suspendendo-a durante $o$ ato de enunciação. Pois, mesmo sob o registro teológico, o mal parasitário de Orígenes, Boécio e Pseudo-Dionísio ainda depende não apenas da recusa, por Deus, em intervir para remover a privação do

10 MILTON, 1943, 91. Ocupando as linhas 25 e 26 do primeiro livro de Paraíso Perdido, o original é: "[That I may] assert eternal providence and justify the ways of God to men". 
universo sensível como também Sua disposição em preservar a substância boa que sustenta sua existência parasitária. Como Agostinho reconhece e Dante enfatiza ao atribuir a existência de sua città dolente a la divina podestate, la somma sapienza e l' primo amore, a existência do inferno exige a presença nele de algo divino ${ }^{11}$. No que diz respeito ao mal, Deus não é nem eximível, nem extricável - para usar dois neologismos roseanos.

Já o ponto a explicitar é que a ontologia cristã não se restringe a estabelecer uma equivalência entre o cerne do divino e o ser. Em seu extremo, promete também um incerto excedente ao qualificar Deus como uma causa além do ser, da distinção entre ser e não ser e até da compreensão humana. Para escapar do panteísmo - e, assim, da idolatria inerente a qualquer associação entre o Criador (ou a Criadora) e o cosmo criado -, a teologia é obrigada a recorrer à negação também quando fala do divino. Se o diabo não é por ser a privação do que é, Deus tampouco é - pois supera não apenas o próprio ser, como também qualquer categoria que possa ser expressa por tortas palavras. Ou, como diz Pseudo-Dionísio ainda no início de Os nomes divinos:

O bem além da palavra é impronunciável. [E é] essência além da essência e mente inconcebível e palavra impronunciável e a falta de fala e falta de conceito e falta de nome - sendo assim à maneira de nenhum ser existente, origem de todo ser sem ele próprio (aition men tou einai pasin, auto de me on) por estar além de toda essência (1:1).

Ironicamente, a negatividade usada para tipificar o diabo retorna no discurso sobre Deus. O registro, entretanto, é outro: deslocou-se da ontologia para a epistemologia. A mesma negação que estabelecia a vacuidade ontológica do mal agora enfatiza o caráter inefável daquele deus alienus que Pseudo-Dionísio descreve como tes huperousiou kai krufias Theotetos, como "a divindade hiper-essencial e oculta (1:1)". Trata-se de um procedimento poderoso, cujo impacto surge não das hipérboles que o místico cristão cadencia, mas da insuficiência que ato contínuo - atribui às mesmas. Como em toda apófase, a linguagem encontra sua força não no que diz, mas no fracasso que performa e na

11 Confissões (2:2) e Inferno (III: 5-6). Pseudo-Dionísio segue a mesma linha. "Não há coisa existente que venha do mal, nem o mal em si seria se fosse mal também em si", admite em Os nomes divinos (4:19). "E, como não, o mal não é inteiramente mal, mas tem alguma porção do bem (ouk pante kakon to kakon, alla exei tina tagatbou), em função da qual [o mal] existe". 
promessa que faz de um excedente que jamais predica ou revela: o cerne divino, o mais-que-ser além (e aquém) de todo ser.

Não por acidente, essa buperousia perikaluptouses - essa hiper-essência "grande oculta demais" (ROSA, 1984. p. 472) - poderia encontrar equivalente na mais roseana de todas as palavras: ser-tão ${ }^{12}$. Tampouco por acidente, o discurso de Riobaldo sobre o ser-tão compartilha com a apófase bem mais do que a mescla de hipérbole e ênfase na insuficiência das palavras. Compartilha com ela também o evocar, que Derridá (1992) associa à economia das preces, de um "Senhor" autorizado e capaz de avalizar sua tentativa de restaurar e significar o passado que narra. Vale notar como Riobaldo alterna referências ao excesso referencial do sertão, à contingência do seu próprio saber e ao Outro que chama para o espaço pragmático-confessional:

Assim, é como conto. Antes conto as coisas que formaram passado para mim com mais pertença. Vou lhe falar. Lhe falo do sertão. Do que não sei. Um grande sertão! Não sei. Ninguém ainda não sabe. Só umas raríssimas pessoas - e só essas poucas veredas, veredazinhas. O que muito the agradeço é a sua fineza de atenção ${ }^{13}$.

\section{Ausência e representação}

De volta ao sertão, resta uma pergunta. Pois a leitura da ontoteologia cristã como mera reprodução do dualismo maniqueísta, tão moderna quanto redutora, é suficientemente difundida para que seja necessário indagar se Guimarães Rosa conhecia a diabologia cristã em

12 Em seu fascinante ensaio "How to avoid speaking: denials", Derridá ressaltar como tal huperousia remete àquela "idea do Bom" (idea tou agathou) que Platão situa além do próprio inteligível no livro VII da República. Trata-se de um espaço paradoxal, pois promete um terceiro além do dualismo que escapa ao próprio jogo de diferenças que sustenta a linguagem e assim à predicação. Inexpressável, só pode ser aproximado pelo paradoxo. "The beyond of that which is beyond Being, it has the double and ambiguous meaning of what is above in a hierarchy, thus both beyond and more", afirma Derridá (1992, p. 90). "God (is) beyond Being but as such is more (being) than Being; no more being and being more than Being."

13 ROSA, 1984. p. 93. Em diversas ocasiões Riobaldo chega a atribuir ao "Senhor" uma capacidade de compreender a experiência narrada que nega ter. "Conto ao senhor é o que eu sei e o senhor não sabe", confessa (p. 214). "Mas principal quero contar é o que eu não sei se sei, e que pode ser que o senhor saiba." 
geral e o privatio boni em específico. O próprio escritor brasileiro sugere que sim em sua famosa entrevista ao jornalista alemão Gunter Lorenz, a quem diz: "O diabo não existe, por isso ele é tão forte (Em: COUTINHO, 1983. p. 78)”.

Mas a confirmação desse conhecimento encontra-se mesmo na biblioteca de Rosa, hoje abrigada pelo Instituto de Estudos Brasileiros da Universidade de São Paulo. Entre os muitos volumes do acervo, há uma coletânea francesa publicada em 1948 sob o título Satan: études carmelitaines. O livro contém algumas poucas marcações e comentários do escritor brasileiro - sempre econômico em seus apontamentos marginais. Entre os raros trechos que sublinhou com linhas estreitas de tinta vermelha, está uma leitura do romance Monsieur Ouine de Georges Bernanos que menciona a prática dos demônios de levar os homens ao desespero pour les obliger à reconnaître au Mal plus de réalité qu'il n'en $a$, para obrigá-los a reconhecer no mal mais realidade do que ele tem (DESCLÉE DE BROUWER, 1948. p. 552). Com o título, Satan: 'bypostase' du Mensonge, outro artigo enfatiza a privação e o "sem-fim" que constituem o inferno. E tem o seguinte trecho sublinhado por Rosa:

L'abîme, dit l'Apocalypse, est 'sans fond': il ne cesse d'y choir, indéfiniment. Larvatus prodeo... jouons sur les mots, risquons ce calembour: il promène ses larves; aucune forme de l'être ne peut, chez lui, parvenir à maturité (tout état d'être achevé, ce serait quelque chose de Dieu.... ${ }^{14}$ !

Ou seja, Rosa não apenas conhecia a tipificação do mal como uma privação antagônica à huperousia divina como se deu ao trabalho de sublinhar trechos que a expressavam. Mas teologia não é literatura. Suas regras são outras; sua economia simbólica, também. E a tradução, para o regime mimético, da falta radical que Pseudo-Dionísio atribui ao diabólico esbarra um uma impossibilidade: a de se representar qualquer ausência. Pois o mesmo ouk on cuja tipificação era tão adequada ao jogo predicativo resiste à mimese. Afinal, como representar o que não é? Como representar aquilo que é, literal e figurativamente, $a b$ strato? Como transpor para uma tela, escultura ou romance a presença daquele que se apresenta apenas como ausência?

O problema não é de hoje. Como o historiador da arte Luther 14 DESCLÉE DE BROUWER, 1948. p. 248. Os trechos em negrito correspondem aos sublinhados por Rosa: $\mathrm{O}$ abismo, diz o Apocalipse, é 'sem fundo': ele não cessa de cair [...] todo estado de ser atingido seria algo de Deus". 
Link ressalta em sua discussão sobre Giotto em O diabo: máscara sem rosto, a impossibilidade de representar essa falta radical foi sempre um desafio para as artes plásticas, desafio que rendeu ao diabo uma iconografia muito mais rica e plural do que a dos outros personagens bíblicos (LINK, 1998. p. 150 e p. 20). Também foi um desafio para Goethe, com seu Mefistófeles que "sempre nega" - mas ainda assim fala, age e existe. E o mesmo pode ser dito no caso de Dante, cujo Dite - eternamente congelado na geleira de Cocito, em uma paródia impotente e horrenda da onipotência divina - ainda assim existe ${ }^{15}$. O que não é, não se vê.

E é precisamente diante dessa dificuldade secular que Rosa melhor demonstra seu brilhantismo em Grande Sertão - livro em última e primeira instância sobre um homem que teme ter vendido a alma a um diabo que nunca viu e que jamais se personifica ou revela na trama. Ao compor o romance como a confissão de um pseudo-pactário obcecado por "um-que-não-existe" (ROSA, 1984. p. 82 e 130), o escritor brasileiro transpõe - para o regime mimético - a mesma hipóstase da privação que a ontologia predicativa atribui ao diabólico. Trata-se de um procedimento cujo gênio reside na recusa à adaptação: seu sucesso deriva precisamente do caráter direto e literal que impõe à transposição, negando-se a apresentar qualquer hipóstase que atribua realidade ou presença ao mal.

Como diversos estudiosos já ressaltaram, tal elisão da presença diabólica tem profundas conseqüências miméticas, epistemológicas, éticas e estruturais - servindo como matriz da poética roseana. Walnice Nogueira Galvão, por exemplo, é perspicaz ao retratar a ida de Riobaldo às Veredas Mortas como um esforço malfadado - e, em última instância, blasfemo - de impor uma estabilidade artificial a uma ordem das coisas por definição movediça, ao "tudo incerto, tudo certo" do sertão (ROSA, 1984. p. 146). Tendo a fixidez em sua mesma etimologia, o pacto - do Latim pactum, "contrato", do Grego pegnunai, "atar" ou "solidificar" - seria assim:

[Uma busca pela] garantia de certeza, o certo dentro do incerto, a certeza que mata e dana: morte real e morte abstrata. O pacto, como o crime, é algo que atenta contra a natureza do existir, na sua fluidez, na sua permanente transformação. É a tentativa de ter uma certeza dentro da incerteza

15 É sintomático que Dante poeta reitere, em duas ocasiões do Inferno, sua incapacidade de descrever o que encontrou no fim do "abismo do mal" - confessando que apenas "con paura il metto in metro" (XXXIV: 10). 
do viver. (GALVÃO, 1972. p. 121).

João Adolfo Hansen aprofunda (e, aparentemente, inverte) tal leitura. Apresenta "o O" - um dos cem nomes que Riobaldo usa para indicar aquela alteridade difusa e multifacetada que, em Marcos, já se dissera "legião" (5: 12) - como um registro da privação não apenas ontológica, mas também semântica, do diabólico. Enfatizando a vacuidade referencial gerada pela polissemia de "o O", Hansen apresenta o nada que "não queria existir" (ROSA, 1984. p. 394) nas veredas como uma personificação da indeterminação - mas também da potencialidade - verbal que contamina a identidade com a alteridade:

Sendo também um dos nomes do Diabo "O O" zero, nonada, nada, (não)-ser - lê-se nesse nome intensivo e extensivo ou um pronome demonstrativo de terceira pessoa $[\ldots]$ ou, ainda, nele se lê um artigo, determinante elevado à classe de nome, como substancialização da qualidade, que se transforma numa espécie de ser da designação, pura deixis rebaixada para aquém de uma qualidade fixa, pois todos os nomes e todas as coisas podem ser usados como tradução de "O O" ou como seus lugares de emergência e possessão. (HANSEN, 2000. pp. 90-91).

O "Que-Não-Fala" de Grande Sertão (p. 380) seria assim para Hansen um quodlibet, pura "potência de designação [...] 'o incerto no certo': vazio, nonsense, efeito, ao passo que o efeito-certeza é a metáfora de Deus" (2000. p. 91). Seria mais a eterna possibilidade de a não-identidade emergir no seio da identidade do que aquele (não) ser "solto, por si, cidadão" (ROSA, 1984. p.10) cuja manifestação seria suficiente para emprestar ao negativo uma estabilidade, uma equivalência consigo mesmo que o tornaria conhecível. Ainda que seja "sem parar", "o demônio não existe real" (Idem. p. 289): existe no "homem humano" (Idem. p. 568). Como o arkon joanino, "vige dentro do homem" e das coisas, regulando "seu estado preto, nas criaturas, nas mulheres, nos homens [...] e nos usos, nas plantas, nas águas, na terra, no vento... Estrumes" (Idem. p. 10).

À primeira vista, há uma disjunção entre o "certo dentro do incerto" do qual fala Galvão e o "o incerto no certo" de Hansen. Mas o desencontro é aparente. Pois as duas leituras têm objetos diferentes: a de Galvão, o diabo que Riobaldo busca nas Veredas Mortas; a de Hansen, o diabolos que encontra. Como o Fausto de Marlowe - que conclama 
Mefistófeles para resolve me of all ambiguities, para "resolver-me às ambigüidades todas" (I, 80) - Riobaldo busca no pacto a certeza e a unificação. "E, o que era que eu queria?", confessa a seu interlocutor (ROSA, 1984. p. 392). "Ah, acho que não queria mesmo nada, de tanto que eu queria só tudo. Uma coisa, a coisa, esta coisa: eu somente queria era - ficar sendo!" O que o jagunço encontra, entretanto, é precisamente o oposto. Na encruzilhada, depara-se com a incerteza do nada irrestrito - nada marcado por uma cadência de faltas e um excesso de si: "silêncio", "frio", "buracão", "falso imaginado" e - acima de tudo - "a gente mesmo, demais" (Idem. pp. 394-395).

É preciso, portanto, reconhecer em Grande Sertão pelo menos dois diabos. Clássico, o primeiro se resume à privação manifesta do Cristianismo que outorgaria (por contraste) plenitude ontológica ao divino e subsidiaria (por presença) a busca, pelo indivíduo, da determinação histórica e da certeza teleológica. Já o segundo é a ausência do primeiro. Em um eterno denegar (e renegar) epistemológico, é a falta daquela hipóstase da privação que determinaria - por sua mesma negatividade - o ser como presença, predicando a matéria vertente do viver.

A ironia da transposição literal da privatio boni da teologia para a mimese é que, sob uma perspectiva roseana, o diabo clássico revelase não terrível, mas confortante em sua capacidade de delimitar o divino e até ratificar Sua existência. Pois é apenas quando falha em faltar no sertão que o diabo instaura o verdadeiramente dia-bólico, revelando a artificialidade daquela convergência entre significante e significado que constitui o símbolo. Em Rosa, o maior artifício do diabo não é contaminar a substância com a privação. Tampouco é persuadir a humanidade de sua inexistência, como sugere Baudelaire em Le joueur généreux. É não existir, inexistir no espaço a ele reservado. Não sendo em si, o demo - corruptela na qual Marinho (2001. p. 24) identifica o neologismo francófono de-mot, despalavra - torna-se mera figura, o nome provisório do que nem é nem pode ser localizado:

Tem até tortas raças de pedras, horrorosas, venenosas - que estragam mortal a água, se estão jazendo em fundo de poço; o diabo dentro delas dorme: são o demo. Se sabe? E o demo - que é só assim o significado dum azougue maligno tem ordem de seguir o caminho dele, tem licença para campear?! Arre, ele está misturado em tudo. (ROSA, 1984. p. 11). 
O diabólico torna-se assim a ausência, a falta de um diabo predicável, presente e cognoscível. Pois sua mesma falta no sertão roseano expressa a dúvida inerente a um mundo sempre "muito misturado" - indefinição tormentosa para quem deseja que "o bom seja bom e o ruim ruim, que dum lado esteja o preto e do outro o branco [e que estejam] os todos pastos demarcados ${ }^{16 "}$. Daí o artigo que se repete eternamente e eternamente sugere a falta que não manifesta, o substantivo que não se realiza: "o O". O diabo roseano difere de (e a) si mesmo: muito além da não-identidade entre a identidade e a não-identidade, sua economia é a da não-identidade da não-identidade consigo própria. Por isso "existe e não existe" (Idem. p. 9).

\section{O pseudo-pactário e as Veredas Mortas}

Ainda que simples, o procedimento de literalizar a privação diabólica é também subversivo. Pois, ao deslocar a privatio boni da predicação ontológica para a representação romanesca, Rosa também a resignifica. Longe de autorizar a teodicéia de contrastes, seu artifício devolve à experiência real o mal que a teologia deslocara para a abstração metafísica. A economia desse retorno, entretanto, não é a da repetição. É a da transformação - e da tarefa. Pois o diabo retorna ao aqui narrado com toda a negatividade herdada dos teólogos. Não mais uma ausência manifesta, torna-se a ausência de sua própria manifestação - ausência que, por prometer um sentido jamais constituído, acaba tornando-se um ponto zero verbal, um local de infinita potencialidade de significação. No sertão, o diabo nem é, nem significa. Por isso, há de se falar dele.

Ou seja, o assombro do narrador Riobaldo - sua thauma, para usar o termo com o qual "João" descreve os condenados no Apocalip$\boldsymbol{s}$ - não deixa de ser o do pecador que teme o juízo. Tampouco deixa de ser o do tentado que busca compreender a origem de sua tentação. Mas é, sobretudo, o de um eu provisório que - ao buscar aquela privação encarnada cuja presença bastaria para inferir a existência do divino - depara-se com uma indeterminação irrestrita à qual atribui a tarefa de encontrar o excedente "desconhecido [...] duvidável" que lhe falta

16 ROSA, 1984. 206-207. Vale aqui ressaltar uma curiosidade: o fato da demarcação estar na própria origem da palavra "hermenêutica". "Hermes, etymologically "he of the stone heap,' was associated with boundary stones", ressalta Crapanzano (1992. p. 44). "The herm, a head and a phallus on a pillar, later replaced the stone heap". 
(ROSA, 1984. p. 392). Em uma heteronomia radical, Riobaldo atribui seu "ficar sendo", seu próprio porvir, à falsa presença do nada. Ou, como confessa o jagunço:

O demo existe? Só se existe o estilo dele, solto, sem um ente próprio - feito remanchas n'água. A saúde da gente entra no perigo daquilo, feito num calor, num frio. Eu, então? Ao que fui, na encruzilhada, à meia-noite nas Veredas Mortas. Atravessei meus fantasmas? Assim mais eu pensei, esse sistema, assim eu menos penso. O que era para haver, se houvesse, mas que não houve: esse negócio. Se pois o Cujo nem não me apareceu, quando esperei, chamei por ele? Vendi minha alma algum? Vendi minha alma a quem não existe? Não será o pior? (Idem. p. 451)

Mas o que há de subversivo nesse nada que o jagunço encontra nas Veredas Mortas? Acima de tudo, ele revela a contradição inerente tanto à teoria da privação quanto às tentativas clássicas de retratar o diabólico como ausência presente: o fato de tal retrato constituir um oxímoro representacional, o equivalente mimético de um paradoxo recursivo $^{17}$. A originalidade de Rosa reside em que ele reserva para $o$ diabo um espaço representacional privilegiado (o livro é, afinal, sobre um pacto), mas recusa-se a preencher tal espaço com qualquer hipóstase da falta capaz de avalizar a ontologia cristã. Levando a privação ao extremo da inexistência, transforma o demo não em um ente adversativo, mas em um local desocupado cuja vacância empurra a teodicéia de contraste ao absurdo e ao colapso.

Pois ao negar o diabo, Rosa explicita a função constitutiva que ele exerce no mesmo Cristianismo que atribui a ele uma externalidade radical. Longe de escapar ao sistema cristão, o diabo desempenha nele um papel fundamental - e diametralmente oposto ao daquele centro descrito por Jaques Derrida como o ponto único que "comandando [uma] estrutura, escapa à estruturalidade" por não participar dos jogos que possibilita (2002. p 230). Plural, heterogêneo e indeterminado, ocupa o espaço contraditório da alteridade radical que define - por justaposição - as permutações, substituições e transformações da estru-

17 Por recursivos, entendo enunciados reflexivos que referenciam a si mesmos, como: Isso é uma frase. Por paradoxo recursivo, entendo enunciados reflexivos que contradizem a si mesmos, como: Essa frase é falsa. Sobre o tema, ver: HOFSTADTER, Douglas. Gödel, Escher, Bach: an Eternal Golden Braid. New York: Random House, 1999. 
tura que a exclui: constitui, por assim dizer, sua circunferência, a série de pontos limítrofes e diferenças que delimitam o sistema.

Ainda que subverta o contraste ontológico, a apropriação roseana da privatio boni não rejeita a teodicéia em si. Muito pelo contrário, amplifica sua importância ao transformá-la em tarefa do eu falante. No realismo místico de Rosa, o único lócus possível para a justificativa do divino é a "matéria vertente" (ROSA, 1984. p. 91) do vivido. A despeito do testemunho ao e da aparente concordância pelo "senhor [...] soberano, circunspecto ${ }^{18}$ " que o escuta, a responsabilidade pela teodicéia é por definição do narrador. Como é ele o sujeito confessional, qualquer apologia que originasse fora da vivência imediata seria artificial e metafísica. Não por acidente, Riobaldo repetidamente frisa a seu interlocutor o caráter intransmissível da experiência cujo sentido busca - mais que resgatar - constituir:

O senhor viu onça: boca de lado e lado, raivável, pelos filhos? Viu rusgo de touro no alto campo, brabejando; cobra jararacuçu emendando sete botes estalados; bando doido de queixadas se passantes, dando febre no mato? E o senhor não viu o Reinaldo guerrear! ... Essas coisas se acreditam. O demônio na rua, no meio do redemunho... Falo! (Idem. p. 148)

Daí o caráter agônico e provisório da fala de Riobaldo, cujas palavras buscam para a vida um sentido - termo a compreender em sua tríplice acepção de "significado", de "direção" e da "paixão" de um sentir passado. Em uma teodicéia de monismo extremo, cabe ao pseudopactário encontrar nos fragmentos da experiência um propósito. Daí também a modernidade de Guimarães Rosa. Pois o que está em jogo no contar riobaldiano não é tão somente o reconhecimento da culpa ou mesmo a busca pela compreensão em uma vida que "não é entendível" (Idem. p. 131). É também a tarefa, pelo sujeito confessional, de reconhecer em suas palavras o único local possível para uma convergência entre determinação teleológica e contingência vivida - reconhecimento que é o oposto de um pacto.

18 ROSA, 1984. p. 568. Sintomaticamente, Riobaldo jamais usa a palavra "senhor" em sua acepção religiosa - mais do que comum no linguajar sertanejo. 


\section{Referências}

AgOSTINHO DE HIPONA. Confissões. Trad. Alex Marins. São Paulo: Martin Claret, 2002.

. Confessions and Enchiridion. Trad. para

o Inglês de Albert C. Outler. Philadelphia: Westminster, 1955. 216p e $51 \mathrm{p}$.

. The writings against the manichaeans and

against the donatists. Trad. para o Inglês de Philip Schaff. New York: The Christian Literature Publishing, 1890. 651 p.

BÍBLIA. Português. Edição Almeida corrigida fiel. São Paulo: Soc. Bíblica Trinitariana do Brasil, 1994.

BÍBLIA. Novo Testamento trilíngüe: grego, português, inglês. São Paulo: Vida Nova, 1998.

BOÉCIO, Anicius Manlius Severinus. Consolatio philosophiae. Edit. por James O'Donnell. Disponível em http://etext.lib.virginia.edu/latim/ boethius/boecons.html. Acesso em: 28 de julho de 2008.

BURTON RUSSELL, Jeffrey. The prince of darkness: radical evil and the power of good in history. Ithaca: Cornell, 1988.

COUTINHO, Eduardo Faria (org.). Guimarães Rosa. RJ: Civilização Brasileira, 1983.

COWARD, Howard. Derrida and negative theology. Albany: SUNY, 1992.

CRAPANZANO, Vincent. Hermes' dilemma \& Hamlet's desire: on the epistemology of interpretation. Cambridge: Harvard Press, 1992.

DANTE ALIGHIERE. The Divine Comedy: italian text and translation. Trad. para o Inglês de Charles Singleton. Princeton: Princeton Press, 
1970.

DESCLÉE DE BROUWER. Satan: études carmelitaines. Paris: Desclée de Brouwer, 1948.

DERRIDA, Jaques. Escritura e diferença. São Paulo: Perspectiva, 2002.

GALVÃO, Walnice Nogueira. As formas do falso: um estudo sobre a ambigüidade no Grande Sertão: Veredas. São Paulo: Perspectiva, 1972.

GOWAN, Donald. Theology in exodus. Louisville: John Knop Press, 1994.

HANSEN, João Adolfo. O O: a ficção da literatura em Grande Sertão: Veredas. São Paulo: Hedra, 2000.

GREGÓRIO O GRANDE. Moralia. Disponível em < http://iteadjmj.com/ PATROW/mor1-5.doc $>$. Acesso em: 28 de julho de 2008.

GUIMARÃES ROSA, João. Grande Sertão: Veredas. Rio de Janeiro: Nova Fronteira, 1984.

LINK. Luther. O diabo: a máscara sem rosto. São Paulo: Companhia das Letras, 1998.

MARINHO, Marcelo. Grnd sert : vertigens de um enigma. Campo Grande, Letra Livre, 2001.

MARLOWE, Christopher. The tragical history of Dr. Faustus. New York: Collier \& Son, 1909.

MILES, Jack. Deus: uma biografia. Trad. de José Rubens Siqueira. São Paulo: Companhia das Letras, 1997.

MILTON, John. Paradise lost and other poems. Edit. por Maurice Kelley. NY: Walter J. Black, 1943.

PSEUDO-DIONÍSIO. Peri Theon Onomaton. Disponível em: http:// 
www.documentacatholicaomnia.eu/02g/0531-0533,_Dionysius_ Aeropagita,_De_divinis_nominibus,_MGR.pdf $>$. Acesso em: 28 de julho de 2008.

SCHULER, Donaldo. "O Épico em Grande Sertão: Veredas". In: João Guimarães Rosa. Porto Alegre: URGS, 1969.

TOMÁS DE AQUINO. Suma Teológica. Trad. de Alexandre Corrêa. Caxias do Sul Universidade de Caxias do Sul, 1980. 